\title{
Composition and functional groups of epiedaphic ants (Hymenoptera: Formicidae) in irrigated agroecosystem and in nonagricultural areas
}

\author{
Patricia Hernández-Ruiz ${ }^{(1)}$, Gabriela Castaño-Meneses ${ }^{(1)}$ and Zenón Cano-Santana ${ }^{(1)}$ \\ (1)Universidad Nacional Autónoma de México, Facultad de Ciencias, Departamento de Ecología y Recursos Naturales, Circuito Exterior, s/nº, Ciudad \\ Universitaria, 04510 México, DF, México. E-mail: p.hernandezruiz@yahoo.com.mx, gcm@hp.fciencias.unam.mx, zcs@fciencias.unam.mx
}

\begin{abstract}
The objective of this work was to evaluate the species composition and functional groups of ants in nonagricultural (NA) and in irrigated areas (S, seasonal irrigation; P, irrigation with well water; $\mathrm{W}$, irrigation with wastewater) in an arid agricultural region in central Mexico, throughout 2005 and 2006. A total of 52,358 ants belonging to 6 subfamilies, 21 genera and 39 species was collected using pitfall traps. The species best represented in all plots were: Forelius pruinosus, Pheidole obtusospinosa, Monomorium minimum and Dorymyrmex spp. NA plots recorded the highest density of ants. The highest values for diversity (H') and equitativity ( $\mathrm{J}$ ') were recorded in NA and P plots, while the lowest were recorded in $\mathrm{W}$ plots. Cluster analysis showed two different groups regarding species composition: NA-S and W-P. Functional groups recorded were: dominant Dolichoderinae, three species; subordinate Camponotini, five species; hot climate specialists, three species; tropical climate specialists, seven species; cold climate specialists, five species; cryptic species, one species; opportunists, six species; generalized Myrmicinae, nine species. Agricultural activity affects the structure of the ant community with epiedaphic forage, and the constant use of irrigation wastewater in conjunction with intense agricultural practices has negative effect upon species richness of epiedaphic ants.
\end{abstract}

Index terms: biodiversity, irrigated area, semiarid zone, wastewater.

\section{Composição e grupos funcionais de formigas epiedáficas (Hymenoptera: Formicidae) em agroecossistema irrigado e em áreas não agrícolas}

\begin{abstract}
Resumo - O objetivo deste trabalho foi avaliar a composição de espécies e os grupos funcionais de formigas em áreas não agrícolas (NA) e em áreas irrigadas ( $\mathrm{S}$, irrigação sazonal; $\mathrm{P}$, irrigação com águas de poço; $\mathrm{W}$, irrigação com água residuária) em uma região agrícola de clima árido da região Central do México durante 2005 e 2006. Um total de 52.358 formigas pertencentes a 6 subfamílias, 21 gêneros e 39 espécies foi coletado por meio de armadilhas Pitfall. As espécies mais bem representadas em todas as parcelas foram: Forelius pruinosus, Pheidole obtusospinosa, Monomorium minimum e Dorymyrmex spp. As parcelas NA registraram a maior densidade de formigas. Os maiores valores de diversidade ( $\left.\mathrm{H}^{\prime}\right)$ e equitatividade (J') foram observados nas parcelas NA e $\mathrm{P}$, e os menores, nas parcelas $\mathrm{W}$. A análise de cluster mostrou grupos diferentes quanto à composição de espécies: NA-S e W-P. Os grupos funcionais registrados foram: Dolichoderinae dominantes, três espécies; Camponotini subordinadas, cinco espécies; especialistas de clima quente, três espécies; especialistas de clima tropical, sete espécies; especialistas de clima frio, cinco espécies; espécies crípticas, uma espécie; oportunistas, seis espécies; Myrmicinae generalizados, nove espécies. A atividade de agricultura afeta a estrutura das comunidades das formigas epiedáficas e a utilização constante de irrigação com água residuária, em conjunto com práticas agrícolas intensas tem um efeito negativo na riqueza de espécies de formigas epiedáficas.
\end{abstract}

Termos para indexação: biodiversidade, área irrigada, zona semiárida, água residuária.

\section{Introduction}

Environmental fragmentation due to human activity has contributed dramatically to modify the habitat of animals. Large natural ecosystems have recently been replaced by agricultural ecosystems. This generally causes a decrease in species richness and, consequently, impoverishes the natural landscape (Hole et al., 2005).
Major questions on the study of the role of diversity within agroecosystems are to quantitatively determine the effect of the transformation of ecosystems on regional biodiversity and to evaluate the extent to which such environments contribute to the contemporary landscapes regarding biodiversity (Hole et al., 2005; Sans, 2007).

It has been observed that ants may function as bioindicators, due to their complex ecological 
interactions within their habitat, and to their sensitivity to disturbances (Read \& Andersen, 2000). It is possible to analyze variations in the community of ants under the concept of functional groups, defined in accordance with their tolerance to disturbance and environmental stress, as well as with their ability for competitive interactions (Andersen, 1995).

Continuous irrigation within the investigational area has generated significant changes in the physical and chemical features of the soil (Siebe \& Fisher, 1996), as well as high concentration of organic matter, which enhances the nutritional quality of the soil (Secretaría de Agricultura y Recursos Hidráulicos, 1994; Siebe \& Cifuentes, 1995). This study tested the hypothesis that the structure of the community of epiedaphic ants related to agroecosystems is negatively affected by the intense use of agricultural areas and the frequent use of irrigation water.

The objective of this work was to evaluate the species composition and functional groups of ants in nonagricultural (NA) and in irrigated areas.

\section{Materials and Methods}

This study was carried out in Mezquital Valley, Hidalgo, Mexico, at a height between 1,700 and 2,100 m, in three places: Tezontepec de Aldama $(2,100 \mathrm{~m}$, $\left.20^{\circ} 11^{\prime} \mathrm{N}, 99^{\circ} 16^{\prime} \mathrm{W}\right)$, Mixquiahuala de Juárez $(2,050 \mathrm{~m}$, $\left.20^{\circ} 14^{\prime} \mathrm{N}, 99^{\circ} 12^{\prime} \mathrm{W}\right)$; and San Salvador (1,990 m, 20 $0^{\circ} 16^{\prime} \mathrm{N}$, $98^{\circ} 57^{\prime} \mathrm{W}$ ) (Instituto Nacional de Estadística, Geografia y Informática, 1999).

This region is characterized by a semiarid climate, with summer rains (García, 1987). The annual mean temperature ranges between 12.2 and $23^{\circ} \mathrm{C}$ (Instituto Nacional de Estadística, Geografia y Informática, 1999). The Mezquital Valley shows shallow alluvial calcareous soils (Instituto Nacional de Estadística, Geografia y Informática, 1999). The vegetation in the region is represented by crasicaule scrub, with subinerme scrub and rosette scrub. Genera Acacia spp., Mimosa spp. and Prosopis spp. are the most prominent (Rzedowski, 1981). Due to the agricultural activity, the area has lost almost $50 \%$ of its natural vegetation.

In order to compare the structure of the ant community in various environments based on species richness, composition and functional groups, three places (Tezontepec, Mixquiahuala and San Salvador) were sampled in the dry and wet seasons using 39 plots with different irrigation methods: 6 agricultural areas irrigated with well water $(\mathrm{P}) ; 15$ agricultural areas irrigated with wastewater (W); 9 agricultural areas seasonally irrigated (S); and 9 plots located in nonagricultural areas (NA). Samples were taken throughout two years: NA, W and P plots in 2005, and S plots in 2006. P and W plots were more intensely used since they are artificially irrigated. Seasonal irrigation $(\mathrm{S})$ requires irrigation with summer rainwater.

The following design was applied to two places (San Salvador and Tezontepec): four types of plots (P, W, NA and $S$ ) $x$ two seasons $x$ three plots per type. The design for Mixquiahuala was: three types of plots (W, NA and S) $x$ two seasons, using three NA plots, three $S$ plots and nine $\mathrm{W}$ plots. The sampling design was not balanced for the three sites since at Mixquiahuala there were no crops irrigated with well water, but there was a wide variety of plots with various periods of use being irrigated with wastewater, which generated lower numbers of samples from $\mathrm{P}$ plots and higher numbers of samples in $\mathrm{W}$ plots. Corn and alfalfa monocrops prevailed in agricultural plots, and polycrops (vegetables and ornamental plants) prevailed only in five plots (three of $\mathrm{P}$ and one of $\mathrm{W}$ ).

In every plot, 12 pitfall traps were placed in transects $(8 x 4)$, spaced by $7 \mathrm{~m}$ (Peck et al., 1998). Pitfall traps (75 mm diameter, $500 \mathrm{~mL}$ ) contained car anti-freezing $15 \%$ solution (v/v) (Bardhal, Bardhal Manufacturing Corporation, USA) in $70 \%$ alcohol. All traps were placed and collected on the same weekday, after seven days in the field.

The use of pitfall traps allows to statistically compare diversity treatments and studies on forage ants in open areas and grasslands (Read \& Andersen, 2000; Retana \& Cerdá, 2000; Herrera et al., 2005; Phipps, 2006), as well as in disturbed areas (Ward et al., 2001; Graham et al., 2009); however, it implies certain limitations (Bestelmeyer et al., 2000; Delabie et al., 2000; Longino, 2000) that have to be taken into consideration in the collection technical plan (e.g. distance between barrels and lids, and trap diameter).

Shannon-Wiener diversity index $\left(\mathrm{H}^{\prime}\right)$, equitativity Pielou index (J') and Simpson dominance index $(\lambda)$ were calculated (Zar, 1999) taking absolute frequencies of species. Similarity indexes are given as IS (Sørensen, 1948). A dendogram with relative frequency data was made with the Biodiversity Pro software, version 2 (McAleece, 1997) using the Bray-Curtis method to determine similarities in the composition of species in the various types of plots from traps percentage data of ants in each trap, in accordance with Longino (2000). 
The effect of the type of plot upon ant density was assessed by means of a one-way variance analysis (ANOVA), while significant differences were determined based on a post hoc Tukey test (Zar, 1999). The classification of ants into functional groups in accordance with their response to stress and disturbance was based on Andersen (1995, 1997, 2000).

\section{Results and Discussion}

A total of 52,358 ants (17,832 in the dry season and 34,526 in the wet season) belonging to 39 species, 21 genera and 6 subfamilies were collected (Table 1). The NA plots had the highest species richness (35), while $\mathrm{P}$ and $\mathrm{W}$ plots had the lowest values (25 and 24 respectively).

Nonagricultural plots had higher density of ants than the remaining plots. Likewise, agricultural seasonally irrigated plots $(\mathrm{S})$ recorded higher density than the plots irrigated with wastewater (W) and well water (P) (Table 1).

The highest values for H', $J$ ' and $\lambda$ indexes were recorded in NA (H', 2.64; J', 0.74) and $\mathrm{P}$ plots $\left(\mathrm{H}^{\prime}, 2.63 ; \mathrm{J}, 0.82\right)$, and the lowest values for such parameters were recorded in $\mathrm{W}$ plots $\left(\mathrm{H}^{\prime}, 2.13\right.$; J', $0.67)$, where dominance $(\lambda, 0.33)$ reached the highest value (Table 1).

The highest similarity among communities was recorded between the $\mathrm{W}$ and $\mathrm{P}$ plots, which shared 21 species (IS, 85.7\%), and between the NA and S plots (26 species; IS, 81.3\%). The lowest similarity values were recorded between the NA and W plots (22 species; IS, $74,6 \%$ ). The Cluster analysis showed two groups in accordance with species composition: one including the NA and $\mathrm{S}$ plots and another including the $\mathrm{W}$ and $\mathrm{P}$ plots (Figure 1).

A significant effect of the plot type on the ant density (individuals per trap) was recorded (Table 1). The NA plots recorded the highest ant density, while the $S$ plots recorded an ant density significantly higher than the $\mathrm{W}$ and P plots, which were similar in this parameter.

From 39 species, 13 were the most frequent and abundant in four types of plots. The lowest values, in general, were recorded for the $\mathrm{P}$ and $\mathrm{W}$ plots. The predominant species in all types of plots were: Forelius pruinosus, Pheidole obtusospinosa, Monomorium minimum and Dorymyrmex spp. In plots that were not irrigated (NA and S), Myrmecocystus melliger, Pogonomyrmex barbatus and Pheidole calens were better represented, while in plots continually irrigated (P and W), Tapinoma sessile and Pheidole coracina were more frequent. Temnothorax sp. 2 and Odontomachus clarus were more frequently recorded only for NA plots.

Taking into account the model of functional groups of ants, in accordance with the response to stress and disturbance proposed by Andersen (1995, 1997, 2000), eight functional groups were recorded in the Mezquital Valley: three species of dominant Dolichoderinae (DD); five species of subordinate Camponotini (SC); three species of hot climate specialists (HCS); seven species of tropical climate specialists (TCS); five species of cold climate specialists (CCS); one species of cryptic species (C); six species of opportunists $(\mathrm{O})$; and nine species of generalized Myrmicinae (GM) (Table 1). Classification of material in functional groups was revised by A.N. Andersen. Within the complex of four Dorymyrmex species (D. insanus, D. bureni, D. smithi, and $D$. paiute), $D$. insanus is predominant regarding abundance and frequency. This study was conservatively determined to include every specimens of this genus within the functional group of opportunists $(\mathrm{O})$, but not all the specimens of the group could be differentiated at the species level.

Taking into account relative frequencies of species, different patterns in ant communities were observed regarding the various uses of soil in Valley of Mezquital (Figure 2). From all functional groups, GM represented the highest relative frequency, with $\mathrm{W}$ plots being the highest and NA plots being the lowest. The second most important group was $\mathrm{O}$, with $\mathrm{P}$ plots having the highest percentage. For NA plots, the second most important group was HCS. The third most important groups were: HCS for S and P; O for NA, and DD for $\mathrm{W}$. In the fourth place, the most important were: DD for NA, S and P; and HCS for W.

The richness of genera found in the study is higher (21 with 39 species) than the richness recorded in other studies carried out in natural arid areas in central Mexico (14 genera with 28 species; Ríos-Casanova et al., 2004), and in a previous study carried out in the same area (16 genera with 21 species; Hernández-Ruiz \& Castaño-Meneses, 2006), both with a lower collection effort.

From the higher species richness and average density of NA, it may be inferred that the community of ants benefits from having more stable places, with more diverse local resources (Phipps, 2006). Seasonal 
irrigation (S) plots, which represent an intermediate degree of use of soil in the study, showed the highest richness and density of species in agricultural areas but, when compared to NA, their values were lower, apparently due to the higher disturbance. This caused a negative impact on diversity (in comparison to NA), but not necessarily on ant density, when compared to $\mathrm{P}$ and W (Bardgett \& Cook, 1998).

Seasonal irrigation areas (S), unlike the plots irrigated throughout the year ( $\mathrm{W}$ and $\mathrm{P}$ ), were less

Table 1. Relative frequency (\% of traps) and density (number of individuals per trap; between parentheses) of ant species in nonagricultural and in agricultural areas of Mezquital Valley, Hidalgo, Mexico ${ }^{(1)}$.

\begin{tabular}{|c|c|c|c|c|c|}
\hline \multirow[t]{2}{*}{ Ant species } & \multirow[t]{2}{*}{$\mathrm{FG}^{(-2)}$} & \multirow[t]{2}{*}{ Nonagricultural } & \multicolumn{3}{|c|}{ Agricultural $^{(3)}$} \\
\hline & & & $\mathrm{S}$ & $\mathrm{W}$ & $\mathrm{P}$ \\
\hline \multicolumn{6}{|l|}{ Dolichoderinae } \\
\hline Dorymyrmex spp. & $\mathrm{O}$ & $58.0(36.4)$ & $66.2(6.5)$ & $9.0(0.7)$ & $28.2(1.4)$ \\
\hline Forelius pruinosus & DD & $62.4(9.2)$ & $24.5(15.3)$ & $8.7(0.5)$ & $13.0(0.8)$ \\
\hline Linepithema dispertitum & DD & 0 & $0.5(0.01)$ & $0.4(0.01)$ & 0 \\
\hline Liometopum apiculatum & DD & $0.5(0.005)$ & 0 & 0 & 0 \\
\hline Tapinoma sessile & $\mathrm{O}$ & $0.23(0.002)$ & $1.9(0.04)$ & $17.7(0.5)$ & $18.7(0.5)$ \\
\hline \multicolumn{6}{|l|}{ Ecitoninae } \\
\hline Neivamyrmex harrisii & TCS & $0.7(0.01)$ & 0 & 0 & 0 \\
\hline Neivamyrmex melanocephalus & TCS & $0.2(0.002)$ & 0 & 0 & $0.4(0.004)$ \\
\hline Neivamyrmex swainsonii & TCS & 0 & $0.5(0.06)$ & 0 & 0 \\
\hline Neivamyrmex texanus & TCS & $0.2(0.01)$ & $2.5(0.2)$ & $0.3(0.01)$ & $1.4(0.02)$ \\
\hline \multicolumn{6}{|l|}{ Formicinae } \\
\hline Camponotus atriceps & $\mathrm{SC}$ & $0.2(0.002)$ & 0 & 0 & 0 \\
\hline Camponotus festinatus & $\mathrm{SC}$ & $6.8(0.1)$ & $0.5(0.005)$ & 0 & $0.7(0.01)$ \\
\hline Camponotus sp. 3 & $\mathrm{SC}$ & $2.8(0.04)$ & $0.2(0.002)$ & 0 & 0 \\
\hline Camponotus sp. 4 & $\mathrm{SC}$ & $3.3(0.1)$ & $0.2(0.002)$ & 0 & 0 \\
\hline Camponotus sp. 6 & $\mathrm{SC}$ & $0.7(0.01)$ & $0.2(0.002)$ & $0.3(0.003)$ & $1.1(0.01)$ \\
\hline Myrmecocystus melliger & $\mathrm{HCS}$ & 29.1(1.3) & $26.4(0.7)$ & $0.6(0.01)$ & $2.5(0.03)$ \\
\hline Paratrechina bourbonica & $\mathrm{O}$ & $2.6(0.04)$ & $7.2(0.1)$ & $2.1(0.03)$ & $8.8(0.1)$ \\
\hline Paratrechina terricola & $\mathrm{O}$ & $6.1(0.2)$ & $2.5(0.03)$ & $0.7(0.01)$ & $2.1(0.02)$ \\
\hline \multicolumn{6}{|l|}{ Myrmicinae } \\
\hline Atta mexicana & TCS & $1.6(0.06)$ & $3.7(0.1)$ & 0 & 0 \\
\hline Cardiocondyla emeryi & $\mathrm{O}$ & $2.1(0.1)$ & $0.2(0.002)$ & 0 & $3.9(0.06)$ \\
\hline Crematogaster opaca & GM & $0.2(0.002)$ & $2.8(0.04)$ & $0.1(0.001)$ & 0 \\
\hline Monomorium minimum & GM & $25.1(1.1)$ & $33.6(1.8)$ & $24.8(2.06)$ & $22.9(0.7)$ \\
\hline Pheidole calens & GM & $18.8(0.9)$ & $56.9(3.5)$ & $2.7(0.1)$ & $5.3(0.2)$ \\
\hline Pheidole coracina & GM & $8.5(0.3)$ & $3(0.1)$ & $13(0.7)$ & $13.4(0.7)$ \\
\hline Pheidole laevivertex & GM & $7.5(0.3)$ & 0 & $1(0.01)$ & $15.8(0.9)$ \\
\hline Pheidole obtusospinosa & GM & $31.7(10.9)$ & $49.3(4.7)$ & $42.9(4.5)$ & $25.7(1.1))$ \\
\hline Pheidole sp. 1 & GM & $2.1(0.03)$ & $15(0.5)$ & $3.1(0.2)$ & $6.7(0.1)$ \\
\hline Pheidole sp. 3 & GM & $0.2(0.002)$ & 0 & $0.3(0.004)$ & 0 \\
\hline Pheidole sp. 4 & GM & 0 & $0.2(0.03)$ & 0 & 0 \\
\hline Pogonomyrmex barbatus & $\mathrm{HCS}$ & $42.7(3.5)$ & $18.5(1.9)$ & $1.6(0.03)$ & $1.8(0.1)$ \\
\hline Solenopsis xyloni & $\mathrm{HCS}$ & $12.4(0.4)$ & $9.5(0.5)$ & $3.3(0.2)$ & $18.3(0.6)$ \\
\hline Temnothorax pergandei & $\mathrm{CCS}$ & $1.4(0.03)$ & 0 & 0 & 0 \\
\hline Temnothorax sp. 1 & $\mathrm{CCS}$ & $1.9(0.02)$ & $0.5(0.005)$ & $0.1(0.001)$ & $1.8(0.02)$ \\
\hline Temnothorax sp. 2 & $\mathrm{CCS}$ & $10.88(0.2)$ & $5.1(0.06)$ & $0.3(0.003)$ & $2.5(0.03)$ \\
\hline Temnothorax sp. 3 & $\mathrm{CCS}$ & $2.8(0.06)$ & $5.8(0.1)$ & $0.6(0.006)$ & $0.7(0.03)$ \\
\hline Temnothorax sp. 4 & $\mathrm{CCS}$ & $1.2(0.02)$ & 0 & 0 & 0 \\
\hline Trachymyrmex sp. & TCS & $0.2(0.002)$ & 0 & 0 & 0 \\
\hline \multicolumn{6}{|l|}{ Ponerinae } \\
\hline Hypoponera sp. & $\mathrm{C}$ & 0 & 0 & $0.1(0.001)$ & $0.4(0.004)$ \\
\hline Odontomachus clarus & $\mathrm{O}$ & $8.2(0.1)$ & $1.9(0.03)$ & $0.6(0.006)$ & $0.4(0.004)$ \\
\hline \multicolumn{6}{|l|}{ Pseudomyrmecinae } \\
\hline Pseudomyrmex pallidus & TCS & $0.5(0.005)$ & $0.5(0.005)$ & 0 & $0.4(0.004)$ \\
\hline Number of ants & & 27,838 & 15,743 & 6,688 & 2,089 \\
\hline Species richnes & & 35 & 29 & 24 & 25 \\
\hline Number of traps & & 426 & 432 & 702 & 284 \\
\hline Average density $\pm \mathrm{EE}$ & & $65.4 \pm 9.4 \mathrm{a}$ & $36.4 \pm 6.8 \mathrm{~b}$ & $9.5 \pm 1.4 \mathrm{c}$ & $7.3 \pm 0.8 \mathrm{c}$ \\
\hline Shannon-Wiener diversity & & 2.638 & 2.456 & 2.128 & 2.626 \\
\hline Pielou equitativity & & 0.742 & 0.729 & 0.669 & 0.816 \\
\hline$\underline{\text { Simpson dominance }}$ & & 0.258 & 0.271 & 0.33 & 0.184 \\
\hline
\end{tabular}


affected, maybe due to a lower intensity of use of the soil (Bardgett \& Cook, 1998), since the plot was prepared for a single crop every year. Besides, this area was not subject to continual irrigation, which may constitute an important disturbance for ants. On the other hand, it is possible that constant irrigation limited the nesting of rare species in the region and the foraging of individuals nesting in nearby areas.


Figure 1. Dendrogram of Bray-Curtis Cluster analysis for agricultural and nonagricultural plots in Mezquital Valley, Hidalgo, Mexico.

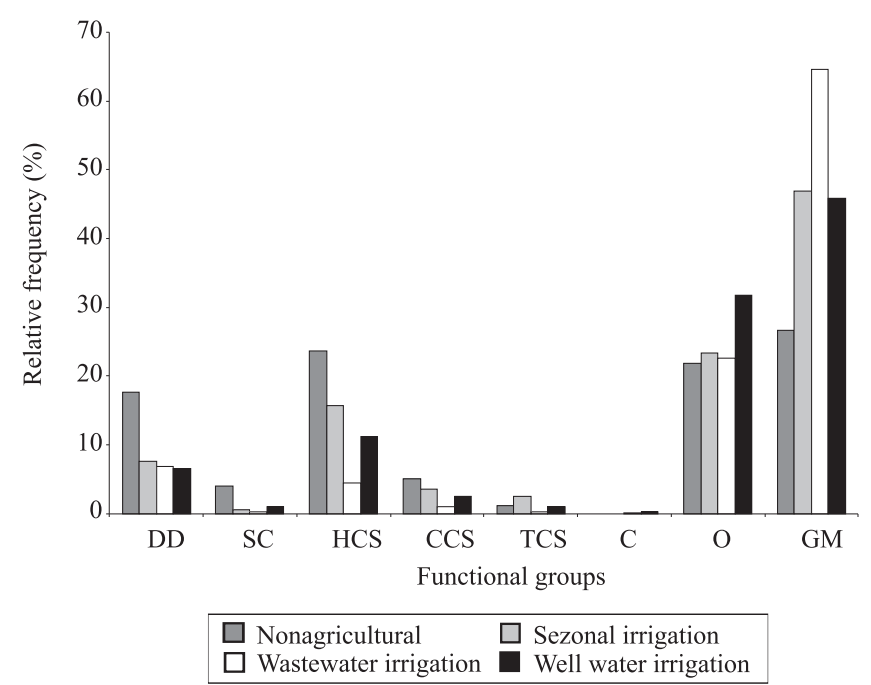

Figure 2. Relative frequency, in percentages of ants from different functional groups (sensu Andersen, 1995, 1997, 2000), in four plots in Valley of Mezquital, Hidalgo, Mexico: NA, nonagricultural; P, irrigated with well water; $\mathrm{W}$, irrigated with wastewater; S, seasonally irrigated. Functional groups: DD, dominant Dolichoderinae; SC, subordinate Camponotini; H/C/TCS, hot/cold/tropical climate specialists; C, cryptic species; O, opportunists; GM, generalized Myrmicinae.
Besides, it is possible that with less agricultural impact, during the following dry season a higher richness of species became apparent. This is due to the diversification of microhabitats, a result from the presence of annual scrubs, favoring stability in the agroecosystem (Bardgett \& Cook, 1998). In this way, seasonal plots may be functioning in a similar way to abandoned areas and that such are functioning as biodiversity refuges (Richter et al., 2007), since ants are less active during the hottest and driest season of the year (Rico-Gray et al., 1998).

The fact that the NA and irrigated with well water (P) plots showed the highest diversity, equitativity and, consequently, the lowest Simpson dominance index, reveals that there is a higher balance in frequency, despite the fact that in P exists an agricultural use.

The difference in specific richness among NA and $\mathrm{P}$ might be due to the fact that there are less species in flooded places (Bihna et al., 2008), but the equality of diversity could be evidencing that the sampling places in NA showed another type of disturbance equivalent to the one caused by the agricultural impact of $P$ plots. However, the highest value of J'in P is an evidency of a more balanced environment than in NA. Therefore, in the studied plots it is not sufficient to take into account the value of diversity, but the equitativity, in order to visualize differences in the community (Graham et al., 2009). In other words, $P$ agricultural plots show a higher environmental stability when compared to the rest of the areas of study, and NA plots show another type of disturbance.

The difference between the values of H', J' and $\lambda$ among $\mathrm{P}$ and $\mathrm{W}$ agricultural plots shows that well water had a less negative effect on the physical and chemical features of the soil due to the quality of this type of water. Water causing a higher fraction of polycrops provides more microenvironments and resources (Herrera et al., 2005; Graham et al., 2009).

The similarity in the composition of the community of ants between S and NA plots as well as between $\mathrm{P}$ and $\mathrm{W}$ plots (Figure 1) could be reflecting similar environments available for ants with epiedaphic forage in semiarid altered environments. Two communities were clearly distinguishable, although the similarity ranges were very close: one typical of nonirrigated areas (with low or no use of soil) and a second one typical of irrigated areas (with high frequency of disturbance related to frequent fallow and use of fertilizers and pesticides). In fact, a gradient in the decrease of species 
richness in the community of ants was observed as the intensity of disturbance increased ( $\mathrm{NA}>\mathrm{S}>\mathrm{P}$ and $\mathrm{W}$ ) (Perfecto et al., 2003; McNeely, 2004).

Clearly in this work, the TCS functional group (Figure 2) decrease significantly in sites, such as: $\mathrm{S}(2.5 \%)>\mathrm{NA}(1.2 \%)>\mathrm{P}(1.0 \%)$ and $\mathrm{W}(0.2 \%)$. Probably, the highest richness found in temporary irrigated plots, where low disturbance is present, allowed the succession of species when compared to nonagricultural areas, where established ant communities do not allowed invasion by other species.

On the other hand, NA plots were characterized by the presence of SC and HCS, which are common in preserved areas and natural arid areas respectively. Groups shown a nonagricultural area where the native fauna of the region might be appearing. Besides the fact of being represented in the four types of plots, the three species recorded in HCS (Table 1) might be showing that certain native fauna has been able to adapt itself to agricultural disturbance in the region. The presence of Tapinoma sessile $(\mathrm{O})$, which is characteristic in rural environments in $\mathrm{P}$ and $\mathrm{W}$ plots, shows a high ecological tolerance.

There are several species which were inefficient as indicators, since they were only recorded for a single type of use of soil due to their low frequency and abundance, such as: Liometopum apiculatum (DD), Camponotus atriceps (SC), Neivamyrmex harrisii, N. swainsonii and Trachymyrmex sp. (from TCS), Temnothorax pergandei (CCS) Hypoponera sp. (C) and Pheidole sp. 4 (GM).

The sampling technique with pitfall traps, widely used for environments with disturbance (Graham et al., 2009) and open areas (Retana \& Cerdá, 2000), benefits this project; however, certain species might be lowered in the collection due to specific features of every species, such as movement and number of individuals per colony (Hölldobler \& Wilson, 1990; Longino, 2000).

The high abundance of GM and $\mathrm{O}$ (characterized by their wide geographical distribution due to their higher resistance to environments with and without disturbance and to their dominance ifDD are not present or are present in lower numbers) in every environment, as well as the absence, in this study, of specialist predators (recorded only for natural environments), and the high overall resemblance in species composition and similarity suggest that there are habitats with certain degrees of disturbance throughout the whole area (Andersen, 1995, 1997).

\section{Conclusions}

1. The predominant ant species in every environment are Forelius pruinosus, Pheidole obtusospinosa, Monomorium minimum and Dorymyrmex spp.

2. The group of tropical climate specialists (TCS) provides the highest specific variation, which helps characterize the types of plots in the Mezquital Valley.

3. Agricultural activity affects the structure of the ant community with epiedaphic forage, and the constant use of irrigation wastewater in conjunction with intense agricultural practices has a negative effect upon species richness of epiedaphic ants.

\section{Acknowledgements}

To the Science Postgraduate Program of Universidad Nacional Autónoma de Mexico and to the Consejo Nacional de Ciencia y Tecnología, for the PHR scholarship (CONACyT - Ref. No. 250013); to Inge Ambrecht (Universidad del Valle, Colombia), Fabiana Cuezzo (Instituto Superior de Entomología, Argentina), Alan Neil Andersen (Commonwealth of Scientific and Industrial Research Organization, Australia), John Longino (The Evergreen State College), and to two anonymous examiners, for the review of the manuscript and their invaluable suggestions; again to Fabiana Cuezzo and John Longino, who also revised the taxonomy of the specimens; to Carmen Maldonado Vargas, Alma Lilia Navarro Vázquez, Jorge Paniagua Nucamendi, Leopoldo Querubín Cutz-Pool, Arturo García Gómez, Aldo Bernal Rojas, Ricardo Iglesias Mendoza, Víctor López, Iván Castellanos and Daniel Estrada-Bárcenas, for the help during the development of the study; to Jaet Garibaldi, for the translation of the manuscript, and Isael Victoria, for his help in the translation of the corrections; to Alma Rosales, for the translation of the Resumo; to Marco A. Romero, for the technical assistance for the use of computing equipment.

\section{References}

ANDERSEN, A.N. A classification of Australian ant communities, based on functional groups which parallel plant life-forms in relation to stress and disturbance. Journal of Biogeography, v.22, p.15-29, 1995.

ANDERSEN, A.N. Functional groups and patterns of organization in North American ant communities: a comparison with Australia. Journal of Biogeography, v.24, p.433-460, 1997.

ANDERSEN, A.N. Global ecology of rainforest ants: functional groups in relation to environmental stress and disturbance. In: AGOSTI, D.; MAJER, J.D.; ALONSO, L.E.; SCHULTZ, T.R. 
(Ed.). Ants: standard methods for measuring and monitoring biodiversity. Washington: Smithsonian Institution, 2000. p.1-8.

BARDGETT, R.D.; COOK, R. Functional aspects of soil animal diversity in agricultural grasslands. Applied Soil Ecology, v.10, p.263-276, 1998.

BESTELMEYER, B.T.; AGOSTI, D.; ALONSO, L.E.; BRANDAO, C.R.F.; BROWN JUNIOR, W.L.; DELABIE, J.H.C.; SILVESTRE, R. Field techniques for the study of ground-dwelling ants. In: AGOSTI, D.; MAJER, J.D.; ALONSO, L.E.; SCHULTZ, T.R. (Ed.). Ants: standard methods for measuring and monitoring biodiversity. Washington: Smithsonian Institution, 2000. p.122-144.

BIHNA, J.H.; VERHAAGH, M.; BRÄNDLE, M.; BRANDL, R. Do secondary forests act as refuges for old growth forest animals? Recovery of ant diversity in the Atlantic forest of Brazil. Biological Conservation, v.141, p.733-743, 2008.

DELABIE, J.H.C.; FISHER, B.L.; MAJER, J.D.; WRIGTH, I.W. Sampling effort and choice of methods. In: AGOSTI, D.; MAJER, J.D.; ALONSO, L.E.; SCHULTZ, T.R. (Ed.). Ants: standard methods for measuring and monitoring biodiversity. Washington: Smithsonian Institution, 2000. p.145-154.

GRAHAM, J.H.; KRZYSIK, A.J.; KOVACIC, D.A.; DUDA, J.J.; FREEMAN, D.C.; EMLEN, J.M.; ZAK, J.C.; LONG, R.W.; WALLACE, M.P.; CHAMBERLIN-GRAHAM, C.; NUTTER, J.P.; BALBACH, H.E. Species richness, equitability, and abundance of ants in disturbed landscapes. Ecological Indicators, v.9, p.866-877, 2009.

HERNÁNDEZ-RUIZ， P.; CASTAÑO-MENESES， G. Ants (Hymenoptera: Formicidae) diversity in agricultural ecosystems at Mezquital Valley, Hidalgo, México. European Journal of Soil Biology, v.42, p.208-212, 2006.

HERRERA, J.; CADENA, P.; SANCLEMENTE, A. Diversidad de la artropofauna en monocultivo y policultivo de maíz (Zea mays) y habichuela (Phaseolus vulgaris). Boletín del Museo de Entomología de la Universidad del Valle, v.6, p.23-31, 2005.

HOLE, D.G.; PERKINS, A.J.; WILSON, J.D.; ALEXANDER, I.H.; GICE, P.V.; EVANS, A.D. Does organic farming benefit biodiversity? Biological Conservation, v.122, p.113-130, 2005.

HÖLlDOBLER, B.; WILSON, O.E. The ants. Cambridge: Belknap, 1990. 733p.

INSTITUTO NACIONAL DE ESTADÍSTICA, GEOGRAFÍA Y INFORMÁTICA. Anuario estadístico del Estado de Hidalgo. Aguascalientes: INEGI, 1999.

LONGINO, J. What to do with the data. In: AGOSTI, D.; MAJER, J.D.; ALONSO, L.E.; SCHULTZ, T.R. (Ed.). Ants: standard methods for measuring and monitoring biodiversity. Washington: Smithsonian Institution, 2000. p.186-203.

MCALEECE, N. Biodiversity professional Beta. Version 2.0. London: The Natural History Museum, 1997.

MCNEELY, J.A. Nature vs. nurture: managing relationships between forests, agroforestry and wild biodiversity. Agroforestry Systems, v.61, p.155-165, 2004.
PECK, S.L.; MCQUAID, B.; CAMPBELL, C.L. Using ant species (Hymenoptera: Formicidae) as a biological indicator of agroecosystem condition. Environmental Entomology, v.27, p.1102-1110, 1998.

PERFECTO, I.; MAS, A.; DIETSCH, T.; VANDERMEER, J. Conservation of biodiversity in coffee agroecosystems: a tri-taxa comparison in southern Mexico. Biodiversity and Conservation, v.12, p.1239-1252, 2003.

PHIPPS, S.J. Biodiversity of ants (Hymenoptera: Formicidae) in restored grasslands of different ages. 2006. 127p. Thesis (Master), University of Missouri, Columbia.

READ, J.L.; ANDERSEN, A.N. The value of ants as early warning bioindicators: responses to pulsed cattle grazing at an Australian arid zone locality. Journal of Environments, v.45, p.231-251, 2000.

RETANA, J.; CERDÁ, X. Patterns of diversity and composition of Mediterranean ground ant communities tracking spatial and temporal variability in the termal environment. Oecologia, v.123, p.436-444. 2000.

RICHTER, A.; KLEIN, A.M.; TSCHARNTKE, T.; TYLIANAKIS, J.M. Abandonment of coffee agroforests increases insect abundance and diversity. Agroforestry Systems, v.69, p.175-182, 2007.

RICO-GRAY, V.; PALACIOS-RIOS, M.; GARCÍA-FRANCO, J.G. Richness and seasonal variation of Ant-Plant associations mediated by plant-derived food resources in the Semiarid Zapotitlán Valley, México. American Midland Naturalist, v.140, p.21-26, 1998.

RÍOS-CASANOVA, L.; VALIENTE-BANUET, A.; RICO-GRAY, V. Las hormigas del Valle de Tehuacan (Hymenoptera: Formicidae): una comparación con otras zonas áridas de México. Acta Zoológica Mexicana, v.20, p.37-54, 2004.

RZEDOWSKI, J. Vegetación de México. Ciudad de México: Limusa, 1981. 432p.

SANS, F.X. La diversidad de los agroecosistemas. Ecosistemas, v.16, p.44-49, 2007.

SECRETARÍADEAGRICULTURAYRECURSOS HIDRÁULICOS. Actualización del estudio geohidrológico del Valle del Mezquital. [S.1.]: Geocalli, 1994. p.161-165.

SIEBE, C.; CIFUENTES, E. Environmental impact of wastewater irrigation in central México: an overview. International Journal of Environmental Health Research, v.5, p.161-173, 1995.

SIEBE, C.; FISHER, W.R. Effect of long-term irrigation with untreated sewage effluents on soil properties and heavy metal adsorption ofleptosols an vertisols in Central Mexico. Zeitschrift für Pflanzenernährung und Bodenkunde, v.159, p.357-364, 1996.

SØRENSEN, T. A method of establishing group of equal amplitude in plant sociology based on similarity in species content and application to analyses of the vegetation on Danish commons. Danske Vidensk Selsk, v.5, p.1-34, 1948.

WARD, D.F.; NEW, T.R.; YEN, A.L. Effects of pitfall trap spacing on the abundance, richness and composition of invertebrate catches. Journal of Insect Conservation, v.5, p.47-53, 2001.

ZAR, J.H. Biostatistical analysis. New Jersey: Prentice Hall, 1999. 663p.

Received on September 9, 2008 and accepted on June 15, 2009

Pesq. agropec. bras., Brasília, v.44, n.8, p.904-910, ago. 2009 